\title{
State Taxation and the Commerce Clause in the Supreme Court, 1938 Term
}

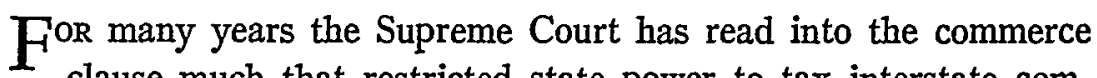
clause much that restricted state power to tax interstate commerce. As a result interstate commerce leaped and bounded across state limes in a comfortable freedom from many of the tax burdens laid upon local commerce and the time came when the latter found itself in need of protection against discriminatory taxation. The Court has been sensitive to this development for its recent decisions greatly liberalize the restrictive effect of earlier interpretations of the commerce clause upon state taxation of interstate commerce. While not abandoning the premise that the propriety of such taxation is subject to judicial as well as Congressional inquiry, it displays a realism in its present approach which augurs well for state taxes affecting interstate commerce so long as their burdens thereupon are not discriminatory. Interstate commerce is no longer an indivisible whole, inviolate from taxation at any point, but an aggregate of component parts which may be separately taxable in various states. Henceforth states may fish in the streams of interstate commerce so long as they do not catch more than their legal limit. That limit will be set by the Court's rules of apportionment, until Congress sees fit "to exercise its constitutional power to alter or abolish the rules thus judicially established." 1

Despite their greatly increased freedom within these limits, however, states will still encounter judicial disapproval whenever they overstep their limits by reaching out for values properly attributable to another state. Thus, in Gwin, White \& Prince, Inc. v. Henneford ${ }^{2}$ the Court invalidated the application of the Washington "business activities" tax to the gross receipts of a domestic corporation from activities in interstate commerce. The corporation made its headquarters in Washington and carried on a general marketing business, selling products of both Washington and Oregon fruit growers in other states and foreign countries and receiving a fixed commission for each box sold. It maintained at numerous points outside the state representatives who negotiated sales, made deliveries and col-

1 Gwin, White \& Prince, Inc. v. Henneford (Jan. 3, 1939) 305 U. S. 434, 441. See Note (1939) 27 CAIIF. L. REv. 336.

2 Supra note 1. 
lected payments which they remitted to headquarters in Washington. It was stipulated that Washington made no claim to tax the Oregon business and the Court was accordingly concerned with the validity of the tax only insofar as it was measured by receipts from Washington shipments.

The Court found that the corporation's gross receipts resulted from services which were exclusively in interstate commerce. It might have rested its decision upon the traditional ground that a state cannot tax gross receipts from interstate commerce, as in fact two of its members did, fortified as they were by a long line of decisions culminating in Puget Sound Co. v. Tax Commission, ${ }^{3}$ decided at the beginning of the previous term. The basis of its decision, however, was that since the state did not apportion its tax to activities within its borders, possibility of similar taxes in other states upon the interstate commerce in question subjected it to the risk of cumulative burdens to which local commerce was not exposed. Thus, the "added reason" for sustaining the tax in the Western Live Stock $k^{4}$ case in the preceding year was absent here and its absence was decisive in determining the Washington tax invalid.

The Court's opinion makes it clear that the tax would have been upheld, had it been apportioned to gross receipts from activities carried on within the state even though those activities were integral parts of the interstate transactions, and thus virtually overrules the Puget Sound Co. case. In the new light of the apportionment theory the Court distinguished Ficklen v. Shelby County Taxing District, ${ }^{5}$ revitalized by the Western Live Stock case and relied upon by the Washington Supreme Court, on the ground that the problem of apportionment in that case was obviated by the fact that all of the activities of the taxpayer were carried on withm the state. In the Gwin case, on the contrary, they were carried on within and without

3 (1937) 302 U. S. 90.

4 Western Live Stock v. Bureau of Revenue (1938) 303 U. S. 250.

5 (1892) 145 U.S.1. Long before the enunciation of the cumulative burdens doctrine this case had been undermined by frequent criticism although it was never specifically overruled. In Brennan v. Titusville (1894) 153 U. S. 289, 306, the Court referred to the Ficklen case as "near the boundary line of the State's power." In Crew Levick Co. v. Pennsylvania (1917) 245 U. S. 292, 296, the Court stated that the taxpayers in the Ficklen case would have fared otherwise had their activities extended only to interstate business. In Raley \& Bros. v. Richardson (1924) 264 U. S. 157, 159, the Court declared that "one cannot avoid a tax upon a taxable business by also engaging in a non-taxable business." See Johnson, Multi-State Taxation of Interstate Sales (1939) 27 CaLIF. L. Rev. 549. 
the taxing state. While a separable intrastate business may have existed in the Grin case, as it did in the Ficklen case, taxability did not turn upon the existence of that business but upon the apportionment of the tax. The implication is clear that the first condition is not essential so long as the second is present, and the Groin case thus marks a distinct advance over the Ficklen case.

The opinion does much to elucidate the cumulative burdens doctrine formulated in the Western Live Stock case and applied in Adams Manufacturing Co. v. Storen. ${ }^{6}$ In all three cases the Court rested its decision exclusively on the commerce clause but its reasoning is sufficiently evocative of the due process clause as interpreted to forbid extrastate taxation to warrant the speculation that the cumulative burdens doctrine might conceivably have been formulated thereunder. To the influence of that clause one might well ascribe the following language:

“... state taxation, whatever its form, is precluded if it discriminates against interstate commerce or undertakes to lay a privilege tax measured by gross receipts derived from activities in such commerce which extend beyond the territorial himits of the taxing state."

Such a statement is akin to the rule governing taxes on the net income of foreign corporations. ${ }^{8}$ The requirement of apportionment in both situations suggests that whatever mechanics prove workable for apportioning net income ${ }^{9}$ inght appropriately be extended to the apportionment of gross incoine or gross receipts.

The taxpayers in Adams Manufacturing Co. v. Storen and the Gwin case were domestic corporations. If, therefore, the apportionment coinpelled by the cumulative burdens doctrine is actually inspired by the due process clause, it will exclude from taxation in one state not only all gross receipts of nonresidents and foreign corporations, but also of domestic corporations and presumably of residents,

6 (1938) 304 U. S. 307.

7 Gwin, White \& Prince, Inc. v. Henneford, supra note 1, at 438-439.

8 Hans Rees' Sons, Inc. v. North Carolina (1931) 283 U. S. 123.

${ }^{9}$ See Underwood Typewriter Co. v. Chamberlain (1920) 254 U. S. 113; Bass, Ratcliff, \& Gretton, Ltd. v. State Tax Comm. (1924) 266 U. S. 271; Hans Rees' Song, Inc. v. North Carolina, supra note 8; People ex rel. Alpha Portland Cement Co. v. Knapp (1920) 230 N. Y. 48, 129 N. E. 202. As applied in the Adams Mfg. Co. case, the apportionment theory would preclude the application to gross receipts taxes of such allocation formulac as were involved in Hump Hairpin Mfg. Co. v. Emmerson (1922) 258 U.S. 290, and Western Cartridge Co. v. Emmerson (1930) 281 U. S. 511, whereby interstate sales were attrihuted to the state of manufacture. 
derived from outside the state even when they do not result from interstate commerce. As a result the rule of Lawrence v. State Tax Commission $n^{10}$ and New York ex rel. Cohn v. Graves ${ }^{11}$ sanctioning the taxation of income of residents from out-of-state sources would extend only to net income taxes. If, however, the rule of apportionment, whatever its inspiration, is regarded as derived entirely from the commerce clause so as to govern the taxation of gross receipts from interstate commerce ouly, the rule of Lawrence v. State Tax Commission and Cohn v. Graves may apply to gross receipts as well as to net income from out-of-state sources except when derived from interstate commerce. In that event the rule of apportionment of the Western Live Stock case and its successors, while adding nothing to a protection already enjoyed by nonresident individuals and foreign corporations under the due process clause, would serve to protect residents and domestic corporations in their activities in interstate commerce.

The Court expounds the cnmulative burdens doctrine to protect the interstate commerce of residents and domestic corporations against the menace of multi-state taxation. In the language of the Court:

"Here the tax, measured by the entire volume of the interstate commerce in which appellant participates, is not apportioned to its activities within the state. If Washington is free to exact such a tax, other states to which the commerce extends may, with equal right, lay a tax similarly measured for the privilege of conducting within their respective territorial limits the activities there which contribute to the service. The present tax, though nominally local, thus in its practical operation discriminates against interstate commerce, since it imposes upon it, merely because interstate commerce is being done, the risk of a multiple burden to which local commerce is not exposed." 12

It is clear that the Court has no objection if each of several states taxes its proper part of the gross receipts from an interstate commerce transaction which partly occurs within its boundaries. A taxpayer who extends his activities through several states is not immune from taxation therein any more than he would be immune from additional taxation if he expanded his activities within one state..$^{13}$ What the Court fears is that more than one state might tax the same gross

10 (1932) 286 U. S. 276.

11 (1937) 300 U. S. 308.

12 Gwin, White \& Prince, Inc. v. Henneford, supra note 1, at 439.

13 Coverdale v. Arkansas-Louisiana Pipe Line Co. (1938) 303 U. S. 604. 
receipts in their entirety. Actually there is no such formidable menace as the Court's language suggests. Even if one state were free to tax all the gross receipts from interstate commerce of an individual by virtue of his residence in the state, or of a corporation by virtue of its being a domestic corporation, other states, far from having the same freedom, would be compelled under the due process clause to limit their taxes to that part of the gross receipts resulting from the activities of the individual or corporation within their respective borders. ${ }^{14} \mathrm{It}$ is true that if the first state taxed the gross receipts in their entirety while the other states laid apportioned taxes thereon, there would be cumulative burdens, not "to the fullest extent," but on that part of the interstate commerce carried on in the latter states. That is a risk, however, to which local commerce may likewise be exposed whenever it is carried on by nonresidents or foreign corporations if the gross receipts thereof may be subjected to taxation not only by the state in which the busmess is carried on but also in the state of residence or imcorporation. Actually, however, there is a strong inference that they cannot be so subjected in the Court's language that local commerce "is not exposed" to such cumulative burdens; but the assumption that it is not exposed gives rise to the speculation that the Court may hold it protected under the due process clause in which case interstate commerce would be similarly protected. If states are forbidden by the due process clause to tax any gross receipts of residents or domestic corporations from out-of-state sources, they are so forbidden whether the gross receipts result from local or interstate commerce. Under those circumstances the imvocation of the commerce clause as an additional protection to gross receipts from interstate commerce would be superfluous.

It may be that the Court invoked the commerce clause rather than the due process clause because it was unwilling to restrict state taxation of the gross receipts of residents and domestic corporations from non-interstate business done in other states. In restricting such taxation with regard to interstate commerce it may have been influenced by the consideration that whatever theoretical equality would otherwise exist between local and interstate commerce would be offset by the actual discrimination against interstate commerce resulting from the fact that more taxpayers would be likely to engage in interstate commerce than to spread their activities in local commerce in several states. It would be small comfort to the first group of taxpayers that

14. Hans Rees' Sons, Inc. v. North Carolina, supra note 8. 
the second group would be exposed to the same cumulative burdens when most taxpayers engaged in local commerce would probably confine their activities to one state and thus never be exposed to such burdens. The prevention of such a discrimination against interstate commerce under this theory, however, creates another discrimination against that smaller group of taxpayers whose activities in local commerce are carried on in inore than one state.

The cumulative burdens doctrine, whether an offshoot of the cominerce clause or the due process clause, far from diminishing the power of states to tax interstate commerce, does much to enlarge it. In prohibiting an unapportioned tax on gross receipts from interstate commerce by any one state the doctrime opens the way to apportioned taxes thereon by any interested states. The multi-state taxes which now loom in prospect for interstate commerce find justification in the extension of that commerce through more than one state, and they will be regarded as legitimate so long as they do not transcend state lines. When they do, they become cumulative burdens subject to invalidation under the rule of the Gwin case.

It would be wrong to conclude that because states cannot reach beyond their borders to tax values in interstate commerce properly attributable to other jurisdictions, they may never tax values in intrastate commerce which have already been taxed elsewhere or which may subsequently be taxed elsewhere. ${ }^{15}$ The cumulative burdens doctrine does not as it stands undermine the validity of a chronological series of burdens by any number of states upon the same basic values when they are identified with intrastate commerce, and only the state which at the moment has jurisdiction over the values taxes them at a given time.

Taxation in one state is not an immunization agamst taxation in other states. As a result values whicl shift from state to state may

15 Compare American Mfg. Co. v. St. Louis (1919) 250 U. S. 459; Hope Natural Gas Co. v. Hall (1927) 274 U. S. 284; Utah Power \& Light Co. v. Pfost (1932) 286 U. S. 165; Heisler v. Thomas Colliery Co. (1922) 260 U. S. 245; Oliver Iron Mining Co. v. Lord (1923) 262 U. S. 172; Lacoste v. Department of Conservation (1924) 263 U. S. 545 ; Federal Compress Co. v. McLean (1934) 291 U. S. 17; with Sonneborn Bros. v. Cureton (1923) 262 U. S. 506; East Ohio Gas Co. v. Tax Comm. (1931) 283 U. S. 465; Southern Natural Gas Corp. v. Alabama (1937) 301 U. S. 148; Interstate Natural Gas Co. v. Stone (Dec. 11, 1939) 60 Sup. Ct. 292, 84 L. ed. Adv. Ops. 247; Henneford v. Silas Mason Co. (1937) 300 U. S. 577; Southern Pacific Co. v. Gallagher (Jan. 30, 1939) 306 U. S. 167; Brown v. Houston (1885) 114 U. S. 622; Pittsburg \& Southern Coal Co. v. Bates (1895) 156 U. S. 577; Susquehanna Coal Co. v. South Amboy (1913) 228 U. S. 665 ; Minnesota v. Blasius (1933) 290 U. S. 1. 
sometimes be more heavily taxed than those which never shift at all, just as they may sometimes be less heavily taxed as a result of the shift than if they had remained in one state. Goods in one state, for example, may bear the burden not only of an excise tax on manufacturing but of an ad valorem tax and a tax on their retail sale, while goods in another state may be free from burdens until the moment of sale or use. It is thus a matter of chance whether out-of-state goods are at an advantage or disadvantage in competition with local goods, and the possibility of the latter situation represents not a discrimination but a risk attendant upon the privilege of receiving government protection in two or more states. Tax burdens will vary from state to state and from product to product; their variability is evidence of the freedom with which states may exercise their taxing power, and it would be a practical impossibility to level them all down to the same plane. A state could not look in all directions at once to determine whence out-of-state goods came, and what manner and amount of burdens they had imcurred along the way, for such a task would involve not only a comparison of burdens on these goods with those on goods of local origin but their comparison in relation to one another, and no state would have the requisite detailed knowledge of the tax systems of every other. Even if it were sometimes readily apparent that out-of-state goods had already sustained burdens in other states exceeding those on local goods a state could not undertake to insure equality to out-of-state goods by foregoing its own tax with respect thereto without relinquishing the substance of its taxing power.

The cumulative burdens doctrine likewise constitutes no real threat to such taxes as were upheld in Oliver Iron Mining Co. v. Lord ${ }^{16}$ Heisler v. Thomas Colliery Co. ${ }^{17}$ and Utah Power $\mathcal{E}$ Light Co. v. Pfost. ${ }^{18}$ The subjects there taxed were successfully identified with intrastate commerce in the respective states, and the values by which they were measured were regarded as within the confines of the respective states at the moment of taxation even when it appeared that shortly thereafter they would enter the channels of interstate commerce and subsequently come within the taxing jurisdiction of another state. Within the same category are the taxes which the Court sustained in American Manufacturing Co. v. St.

\footnotetext{
16. Supra note 15.

17 Ibid.

18 Ibid.
} 
Louis ${ }^{19}$ and Hope Natural Gas Co. v. Hall ${ }^{20}$ on the theory that the value of the goods manufactured or the oil produced was accurately reflected by gross receipts from all sales, including those in interstate commerce and local commerce im other states. A question would arise, however, as to the validity of such a measure whenever it was established that the gross receipts represented not the original value of the goods produced but a value enhanced by the transportation and other services added thereto beyond the borders of the taxing state.

In these cases it is the identification of the subjects taxed with intrastate commerce that established the validity, as it would today, of the unapportioned taxes upon the entire values. Had the subjects been identified at that time with interstate commerce they would have escaped taxation altogether, as they would still escape at least those taxes which were unapportioned. Since the extent of state taxation in such cases therefore hinges upon the classification of the activities taxed as interstate or intrastate commerce, great interest attaches to whatever conditions may indicate their classification. There runs through the opinions of the Court dealing with state taxation of interstate commerce a consistent concern, not with precise definitions of interstate and intrastate commerce, but with the prevention of taxes by one state on values properly attributable to another. Herein may lie the key to the definition of those activities which inight plausibly be classified as either interstate or intrastate commerce, for if the Court's preoccupation is with the proper attribution of values, the manner of their attribution will determine the classification of the activities which constitute their source. When the Court is impelled to attribute the values in their entirety to one state, for such reasons as their derivation from activities rooted in the economic life of the state, or their identification upon entrance into a state with the general mass of property therein, the activities will be identified with intrastate commerce even though the arrival of the values from other states may have been immediate or their departure to other states may be imminent. ${ }^{21}$ On the basis of the Court's reliance in the Western Live Stock case upon American Manufacturing Co. v. St. Louis, together with its distimction of that case in the Adams and Groin cases, it is clear that the Court finds in the nature of such activities as manufacturing sufficient reason for attributing all of the values derived therefrom to the manufacturing state.

19 Ibid.

20 Ibid.

21 See infra pp. 183-184. 
The two conditions which established the validity of the tax in the American Manufacturing Co. case were absent in the Groin case for the state not only included out-of-state values in the measure of the tax but levied it upon a subject which could not be identified with intrastate commerce. Thus the Court stated:

"We need not stop to consider which, if any, of appellant's activities in carrying on its business are in themselves transportation of the fruit in interstate or foreign commerce. For the entire service for which the compensation is paid is in aid of the shipment and sale of merchandise in that commerce." 22

The invalidation of the tax in Adams Manufacturing Co. v. Storen might have been forestalled had the state levied its tax upon manufacturing and used gross receipts, as in the American Manufacturing Co. case, as a yardstick only of the value of the goods manufactured. When it chose instead to tax gross receipts, without apportioning those from interstate commerce to activities within the state, it ran head-on into the cumulative burdens doctrine.

It is interesting to contrast the Court's severe differentiation of a gross receipts tax from an excise tax fairly measured by gross receipts in the Adams case with its leniency in construing the tax in the Western Live Stock $k^{23}$ case, on publication of newspapers and magazimes measured by gross receipts from advertising space, as an excise "on the carrying on of a local business, that of providing and selling advertising space in a published journal...." The Court might easily have defined publication in terms comprehensive enough to include the interstate circulation of the magazine, just as it held broadcasting in the Fisher's Blend ${ }^{24}$ case to include the interstate transmission of radio programs. Publication could be compared as plausibly as broadcasting with the transmission of interstate telephone and telegraph messages. The definition arrived at was undoubtedly influenced by the fact that the tax was measured by gross receipts from advertising alone and not from subscriptions, and that whatever increase in the advertising receipts resulted from out-of-state subscriptions no more affected the validity of the tax than increases in the value of property owned by railroads, resulting from their interstate business, would affect the validity of taxes on such property. The added reason adduced by the Court that the tax on sucl values could not in any event

22305 U. S. at 437.

23 Supra note 4, at 257.

24 Fisher's Blend Station v. Tax Comm. (1936) 297 U. S. 650. 
be duplicated elsewhere would seem to be the basic rather than the supplementary reason for sustaining the tax. Had the Court regarded the tax as reaching values properly attributable to other states it might not liave felt free to define the publication of a magazine with interstate circulation as a local business.

The theory of apportionment formulated by the Court is criticized by Mr. Justice Black, who dissented in the Gwin case as he did in the Adams Manufacturing case of the previous term. He takes the stand that

"... state laws are not invalid under the Commerce Clause unless they actually discriminate against interstate commerce or conflict with a regulation enacted by Congress." 25

It is Mr. Justice Black's view that neither of these conditions is present in the instant case and that the tax is therefore valid. No question is here presented by the second condition since "Congress has not deemed it necessary to prohibit the States from levying taxes measured by gross receipts from interstate commerce." ${ }^{26}$ It is therefore upon the question of discrimination that Mr. Justice Black takes issue with the majority. The latter in his view were not concerned with existing cumulative burdens, for the tax in question was the only one imposed upon the taxpayer's gross receipts; the objective of the inajority therefore was merely to prevent the possibility of cuunnlative burdens at some future date, even at the expense of an actual discrimination against local commerce. In Mr. Justice Black's view such a possibility is so conjectural as not to create an actual discrimination against interstate commerce. He notes that earlier decisions of the Court held that the corporation could not be similarly taxed in other states, so that the risk of discrimination which the Court purported to avoid did not in fact exist. Even if that possibility could materialize, and it could only do so if succeeding taxes were likewise held valid, it would be time enough then to consider whether discrimination were thereby created against interstate coinmerce. The taxes were not discriminatory of themselves, and only in conjunction with each other could they have a discriminatory effect. In that event, he concludes, it would be up to Congress to undertake whatever regulation of the problein it deemed necessary. 
If Mr. Justice Black's reasoning were to prevail and the tax in question were held valid, similar taxes by other states would almost certainly follow, and the risk of cumulative burdens which he mimmizes as conjectural would become very real. The very cases on which he relies as standing between appellant and taxation in other states "where the purcliasers reside" could no longer serve as barriers under his theory that state laws would be valid under the commerce clause so long as they were neither discriminatory nor in conflict with Congressional regulations. The majority in fact made it clear that it could not uphold the tax in question without opening the way to taxes in states where the purchasers reside. As a matter of fact its own theory of apportioninent represents at least a partial withdrawal from earlier decisions and itself signifies a greatly liberalized viewpoint towards taxes traditionally regarded as invalid. Thus, Washington is now free to levy an apportioned tax which will remove the discrimination against local commerce which gave concern to Mr. Justice Black.

If the problein of determining the validity of a state tax were postponed to a day when a similar tax is imposed in another state, validity would turn, as the majority opinion poimts out, not upon the capacity of a tax to obstruct interstate commerce but upon the accidental circumstance that similar taxes have been levied in other states. If the first tax alone were upheld while succeeding ones were invalidated, its validity would turn entirely upon the fortuitous circumstance of having appeared first upon the scene. If the first tax were upheld only until succeeding ones appeared, and then invalidated, the test of its validity before that time would be arbitrary, as it would thereafter. If all of the taxes were upheld on the ground that they were in themselves non-discriminatory, even though in conjunction they discriminated against interstate commerce then the remedy, in the judgment of Mr. Justice Black, should lie with Congress alone.

There is much to be said for the advantages of Congressional legislation emphasized in the dissenting opmion. It is difficult, however, to reconcile the theory that Congress has the sole and exclusive power to regulate interstate commerce with the theory that states are free in the absence of Congressional legislation to levy any except discriminatory taxes thereon. Under the first theory, according to the dissenting opmion, a state would have no right to apportion its share of the taxable income from interstate commerce; yet under the second theory states would be free to levy even unapportioned taxes so long as they were not discriminatory. The explanation of this in- 
consistency may be that Mr. Justice Black took exception less to the apportionment of taxes by states than to the formulation of a theory of apportionment by the court. There is some indication to this effect in his forceful injunction that "the judicial department of our government scrupulously observe its constitutional limitations and that Congress alone should adopt a broad national policy of regulation. . .." 27 Such a declaration marks a milestone in the interpretation of the commerce clause. Here is the expression of a real concern to remove judicial restrictions upon state action with respect to interstate commerce and to subject it only to whatever regulations Congress may deem it necessary to enact. His opimon might well have limited itself to that objective. When he also advances the theory, however, that the Constitution grants to Congress sole and exclusive power to regulate interstate commerce, his opinion becomes broad enough to exclude from the province of such regulation not only the Court but the states themselves. The opinion can be extricated from this contradiction only if it is possible to assume that state laws with respect to interstate commerce do not constitute regulations thereof unless they are discriminatory. It would be difficult to exclude from that classification at least those state laws governing the conduct of interstate commerce, whose whole purpose is regulation. Mr. Justice Black apparently does so, however, in his references to the validity of "state laws" that are neither discriminatory nor in conflict with Congressional legislation. He may have intended to confine his rule of validity to tax laws. This interpretation, leaving aside the question as to whether non-discriminatory taxation is a form of regulation, would go far to release from judicial restrictions the taxing power of the states with regard to interstate commerce but it would leave open to serious question, pending grants of authority by Congress, the validity of all other state laws which, under the rule of Cooley v. Board of Wardens, ${ }^{28}$ regulate subjects of interstate commerce admitting of diversity of regulation.

If the dissenting opinion was aimed at the judicial restrictions upon state power with regard to interstate commerce it might have gained by recognizing outright the power of states as well as of Congress to regulate interstate commerce, and by denying the power of the Court, in the absence of Congressional legislation, to invalidate under the commerce clause any state laws relating to interstate com-

27 Ibid. at 455 .

28 (1852) 53 U. S. (12 How.) 298. 
merce including those which might be discriminatory. It might plausibly be argued, even at this late date, that the constitutional provision that "The Congress shall have Power . . . To regulate Commerce ... among the several States" does not prohibit the states from regulating such commerce but inerely empowers Congress to do so whenever it deems it necessary. Under this theory the validity under the commerce clause of a state tax on interstate commerce would turn, not upon the absence of discrimination, but upon the absence of any conflicting Congressional legislation. The Court would thus be relieved of the incessant task of formulating and reformulating the rules goverming the validity under this clause of state laws bearing on interstate commerce. It would continue, however, to examine their validity under the due process and equal protection clauses, so that persons engaged in interstate cominerce would be assured the same measure of protection under those clauses as persons engaged in any other activities.

The general application of a use tax was upheld in Henneford $v$. Silas Mason Company ${ }^{29}$ but it remained undetermined whether the tax could be applied to property purchased for use in interstate commerce or whether the state in that event could require sellers maintaining places of business within its borders to act as collection agents in its behalf. Southern Pacific Co. v. Gallagher ${ }^{30}$ and Pacific Telephone \& Telegraph Co. v. Gallagher ${ }^{31}$ upheld the application of the California Use $\operatorname{Tax}^{32}$ to property purchased outside the state and brought within its borders for subsequent use in the course of mixed

20 Supra note 15. So well established has the validity of the use tax become that the Court dismissed for want of a substantial federal question in Bacon \& Sons v. Martin (Jan. 3, 1939) 305 U. S. 380, an appeal from a judgment of the Kentucky Court of Appeals sustaining such a tax. The plaintiff contended that the Kentucky tax imposed on "the receipt of cosmetics in the State by a Kentucky retailer" was a tax on the "act of receiving" "articles purchased from manufacturers and dealers in other states and transported to plaintiff at its place of busmess in Kentucky, and hence constituted a direct burden on interstate commerce. Ibid. The state court had held that the word "receipt" was used in the statute in the sense of use following the consummation of the sale, and construed the tax as imposed not on the act of receiving but on the sale and use of the cosmetics by the retailer following receipt, and this construction was binding upon the Supreme Court. It may be noted in passing that the Court did not make the validity of the tax contingent upon the fact that a tax had not been paid in any other state with respect to the sale of the cosmetics.

30 Supra note 15. See (1939) 27 CAIIF. L. REv. 356.

31 (Jan. 30, 1939) 306 U. S. 182.

32 Cal. Stats. 1935, p. 1297. See Traynor, The Califorria Use Tax (1936) 24 CaLIP.

L. REv. 175. 
intrastate and interstate commerce. The Southern Pacific ${ }^{33}$ case involved "tangible personalty purchased out of the state for immediate or subsequent installation in an interstate railway facility." The Telephone case $^{34}$ involved two classes of property-special order equipment immediately installed in buildings devoted to mixed intra and interstate business, and stand-by supplies stored "at points on the system suitable for prompt distribution." Both the transaction which brought the goods into the state and the use to which the goods were put after introduction were protected from state taxation by the commerce clause, and the question turned upon whether there was a taxable event between interstate transportation and interstate use subject to the use tax. Much of the property was shipped directly to the place of use and installed as soon thereafter as possible; most of it was adapted only to railroad or telephone uses; and all of it was stored, if at all, only for brief periods. Nevertheless the Court held ${ }^{35}$ that there intervened between the conclusion of the interstate transit and the beginning of the interstate use a retention and installation of the goods which constituted a taxable event. "The interstate movement was complete," said the Court. "The interstate consumption had not begun." 36

In isolating a taxable event to support the constitutionality of the the tax, the Court held the cases governed by Nashville, Chattanooga \& St. Louis Railreay Co. v. Wallace, ${ }^{37}$ and distinguished Helson and Randolph v. Kentucky $y^{38}$ which held invalid a Kentucky tax on the use of fuel consumed in Kentucky waters in the operation of an interstate ferryboat between Kentucky and Illinois, the fuel being put aboard in Illinois. However weakened the latter decision has been by subsequent decisions upholding taxes on storage, or withdrawal from storage ${ }^{39}$ and by the decisions in the instant cases that property purchased for use in interstate commerce is not used in that commerce while held or installed for use, it would still preclude the taxation of such property as railroad rolling stock which was used in interstate commerce before its first entry into the state and was

33 Supra note 15, at 172.

34 Supra note 31 , at 187.

$35 \mathrm{Mr}$. Justice Butler and Mr. Justice McReynolds dissenting.

36 Southern Pacific Co. v. Gallagher, supra note 15, at 177.

37 (1933) 288 U. S. 249.

38 (1929) 279 U. S. 245.

39 Nashville, Chattanooga etc. Ry. v. Wallace, supra note 37; Edelnan v. Boeing Air Transport Inc. (1933) 289 U. S. 249. 
thereafter used in the state only in interstate commerce. Only by a fine distinction, therefore, does the Court uphold the application of a use tax to railroad supplies while they are stored before use, or to telephone switchboards while they are installed, since the storage and the installation are done in furtherance of interstate commerce by owners who are engaged in interstate commerce. The retention or installation of necessity precedes actual use or consumption in the interstate railroad or telephone systems. It is as essential to the operation of the systems as the actual use itself, and a tax imposed at the moinent of storage or installation is no less a burden than a tax imposed at the inoment of actual use.

Yet at that noment, prior to actual use, the property may be regarded as indistmguishable from the general mass of property within the state, a fact which justifies that state in taxing its entire value ${ }^{40}$ while it conversely prevents the taxation thereof by any other states. Unlike rolling stock or fuel used to propel vehicles in interstate cominerce the property in question became fixed within the state upon its installation. Since it therefore became subject to local ad valorem taxation on its entire value and might accordingly be taxed year after year regardless of its use in interstate commerce it would be unrealistic to prevent one non-recurring tax on its use. When the Court perceived the intervention of a taxable moment between the completion of the interstate transit and the beginung of the interstate use its theoretical differentiation of intrastate and interstate commerce was probably motivated by the practical need for a rule which would make use taxes applicable to property like that in question and at the same time prevent their application to such property as rolling stock. The latter does not become identified with the general mass of property in the state; any property taxes thereon must be apportioned; ${ }^{41}$ and it could not be subjected to use taxes without being exposed to the risk of cumulative burdens in all of the states through which it moved. Some question might arise with respect to rolling stock retained on sidings or otherwise stored pending repairs or new shipments, or used temporarily for local hauls. Such a retention and use within the state, though more substantial than the fragile taxable moment in the Southern Pacific and Telephone cases, would nevertheless probably be classified as in interstate commerce because of the absence of the practical considerations which governed the opposite classification in

40 See last four cases cited in note 15, supra.

41 Johnson Oil Refining Co. v. Oklahoma (1933) 290 U. S. 158. 
the Southern Pacific and Telephone cases. While the moment of retention is longer the same considerations which now exempt the property from unapportioned property taxes would likewise exempt it from use taxes.

The isolation from interstate commerce of a taxable event takes on added significance in connection with the "cumulative burdens" doctrine of the Western Live Stock case. In Southern Pacific Co. v. Gallagher $^{42}$ the Court stated:

"Where a similar levy by other states may be imposed, with consequent multiplicity of exaction on commerce for the same taxable event, local tax of a privilege, measured by total gross receipts from interstate transactions, is considered identical with an exaction on the commerce itself."

The "cumulative burdens" rule would thus seem to be apphicable only to cases where one taxable event is exposed to the taxing power of more than one state, and therefore inapplicable to a taxable event isolated from interstate commerce removed from the taxing power of more than one state. ${ }^{43}$ The Court's recognition of a particular taxable event localized in the state as an appropriate subject for a use tax seems to indicate that a state's use tax will not be invalidated by the risk of sales taxes elsewhere which cannot reach the same taxable event. The California Use Tax Act allows no credit for whatever sales taxes may be paid in any other states but as there was no evidence in the Southern Pacific and Telephone cases of the payment of any such tax the Court held there was no discrimination against interstate commerce, and that it would be time enough to consider that problem when there was evidence of the payment of such taxes in other states. ${ }^{44}$ The Court's willingness to postpone consideration of the question of discrimination until there was evidence not merely of the risk of burdens in other states but of their actual imposition is in sharp contrast to its anticipation of that question in the Groin case where it applied the cumulative burdens doctrine even though only the risk and not the reality existed. If the mere risk of cumulative burdens satisfies the Court's concept of cumulative burdens it

\footnotetext{
42 Supra note 15, at 174-175. Italics added.

43 This limitation is implicit in the Court's decision in Coverdale v. ArkansasLouisiana Pipe Line Co., supra note 13.

14 While the Court in Henneford v. Silas Mason Co., supra note 15, emphasized the degree of equality made possible by the credit provision, it took care to point out that it intended no implication that the credit provision was necessary to the constitutionality of the tax.
} 
must be that it does not consider that doctrine applicable to state use taxes on property coming from other states. Presumably, therefore, it regards such inultiple taxes on the same basic values, not as a pyramid of burdens on interstate commerce, but as a succession of burdens on values which, however freely they move in interstate commerce, are identified at separate times with the intrastate cominerce of separate states. ${ }^{45}$

Apart from theoretical considerations a requirement that a state imposing a use tax give credit for taxes paid to other states would be beset by practical difficulties. It would be extremely difficult for one state to check when and where such taxes had been paid in other states. In some cases the credit might be claimed even before the tax was paid to the seller state, because of different reporting periods in the states. Even if it were feasible for states to make investigations for one another, such factors as the discontinuance of the seller's business or the destruction of his records would make it impracticable to verify claims for credit. The sales tax paid at the state of origin might be subject to a refund, sometimes materializing after the credit had been allowed at the state of destination. Finally, uncertainty would arise as to whether the credit requirement applied not merely to sales taxes but to manufacturers' excise taxes and the variety of other taxes which goods are apt to encounter from their production until their consumption.

With their constitutionality established, use taxes needed only the decision in Felt \& Tarrant Manufacturing Co. v. Gallagher ${ }^{40}$ to insure their practicability. The Court there held constitutional the provision of the California Use Tax Act requiring the collection of the tax from purchasers, for subsequent remittance to the state, by sellers maintaiming places of business within the state. The seller in this case was an Illinois corporation which leased offices in its own name in California, itself paying the rent, for the use of two general agents upon whom it conferred the exclusive right to solicit orders within the state subject to approval of the home office. The offices were used exclusively in furthering the business of the corporation and the agents devoted themselves entirely to soliciting orders for the corporation. It agreed to contribute a fixed amount toward the salaries of deinonstrators as well as toward the traveling expenses of the agents, their subagents and demonstrators. All sales receipts were

45 See supra pp. 173-175.

46 (Jan. 30, 1939) 306 U. S. 62. See (1939) 27 CALIF. L. Rev. 360. 
paid directly to the corporation and all machines delivered in California were shipped from one of the corporation's distributing points outside the state, sometimes directly to the purchasers and sometimes to the general agents for delivery to the purchasers. The corporation contended that it did no intrastate busmess in California, and that therefore any requirements that it act as the state's collecting agent for the use tax, or that it insure payment if it failed to make collections from the users, constituted a direct burden upon interstate commerce as well as a denial of due process of law.

In upholding these requirements, thereby enabling states to avoid the effect of decisions invalidating taxes on sellers in interstate commerce, the Court relied principally upon Monamotor Oil Co. v. Johnson, ${ }^{4 \pi}$ sanctioning the application of the collection provision in an Iowa fuel tax law with respect to a sale in interstate commerce made by a seller whose busmess in the state included both local and interstate sales. This case was directly in point on the commerce clause issue, for the obligation imposed upon the seller to collect the tax with respect to its interstate sales of property was precisely the same in each case, regardless of whether or not the Felt and Tarrant Company was engaged exclusively in interstate commerce.

The Court disposed of the due process issue by its statement of agreement with the view of the trial court that this issue, as well as the one based on the commerce clause, was foreclosed by Bowman $v$. Continental Oil Co., ${ }^{48}$ Monamotor Oil Co. v. Johnson ${ }^{49}$ and Henneford $v$. Silas Mason Co. ${ }^{50}$ The Silas Mason case, however, was limited to the validity of a use tax, and the Bowman and Monamotor cases were limited to the validity of certain statutory requirements with respect to sales in interstate commerce by sellers engaged in both interstate and intrastate commerce, so they are not conclusive on the due process issue. Nevertheless that issue was squarely presented in the instant case, and whatever consideration the Court gave it, its decision therein establishes that the state had sufficient jurisdiction over the sellers to require them to collect and remit the tax.

It is clear that the state will have jurisdiction only if the Court regards the seller as within the state, but the circumstances establishing that presence will vary from case to case. They will in all likelihood include at least those circumstances necessary for valid service

47 (1934) 292 U. S. 86.

48 (1921) 256 U.S. 642.

49 Supra note 47.

50 Supra note 15. 
of process; even in that field, however, the mininiun requirements have yet to be fixed. Thus in International Harvester Co. v. Kentucky, ${ }^{51}$ upholding the jurisdiction of a state with respect to the service of process upon the local agent of a firm doing a wholly interstate business in the state, the agent was empowered to receive payments. In People's Tobacco Co. v. American Tobacco Co. ${ }^{52}$ the Court in denying jurisdiction stressed the agent's lack of such a power; yet it upheld the jurisdiction of the state in the Felt $\&$ Tarrant Co. case where the agents hikewise lacked the power to receive payments. This factor is therefore not controlling, and it remains uncertain how important the Court regarded the other factors which appeared in the Felt $\mathcal{E}$ Tarrant case. ${ }^{53}$ It seems nevertheless plausible that the Court's present disposition to reduce the protection of interstate commerce from state taxation will be accompanied by a liberal interpretation of the due process clause which will facilitate rather than frustrate the achievement of that objective. It may well be that the Court will regard the mere presence of soliciting agents as sufficient to bring the seller within the state.

There remains unanswered the question of the sanctions that may be imposed for the failure of a retailer to comply with the requirement that it collect and remit to the state the amount of the tax. The California Use Tax Act provides that the tax which the retailer is required to collect "shall constitute a debt owed by the retailer to this State." ${ }^{54}$ The retailer in the Felt \& Tarrant case contended that Califorma could not make it insure payment of any use tax which it does not collect from the users. In arriving at its ruling against the retailer, the Court merely recited this contention amongst others but gave no intimation that it was withholding any decision thereon until future consideration. It is to be noted, however, that since the Felt $\&$ Tarrant case arose from a suit to enjoin the state from enforcing the retailer to collect the tax, the question at issue was not the extent of its obligation but whether it was subject to any obligation at all.

Even if the retailer were held not to be an insurer of the tax, he

51 (1914) 234 U. S. 579.

52 (1918) 246 U. S. 79.

53 See Natural Gas Pipeline Co. v. Slattery (1937) 302 U. S. 300, which upheld the imposition upon a foreign corporation engaged exclusively in interstate commerce of a requirement to furnish a state commerce commission with imformation from affiliated interests of public utilities, and denied the contention that such a requirement violated the commerce clause or the Fourteenth Amendinent.

54 Cal. Stats. 1935, p. 1300, §6. 
could still be required to make reasonable efforts to collect it, and the question then arises as to what constitutes reasonable efforts. That question simmers down to whether it is reasonable to require the retailer to collect the tax at the tine of the sale, ${ }^{55}$ for in this manner he could preclude any subsequent refusal of the purchaser to pay the tax, and thus obviate any responsibility for failure to collect in the event of the purchaser's insolvency, or any expense of collection by suit in the event of his solvency. A requirement of collection at the time of sale, however, would restrict the freedom of those retailers doing busmess on a credit basis who find it advantageous to require no down payments. In either credit or cash sales collection at the time of sale is bound to precede the taxable use of the goods purchased, ${ }^{56}$ thereby raising the question whether the Act is extraterritorial in its operation. The force of these objections is greatly diminished by the Court's recognition that the tax is valid and that the retailer is under some obligation to collect it. Since the Court recognizes so much it would probably sanction a requirement that the retailer collect the tax at a time when he can most practicably insure its payment by the user. To do otherwise would not only interfere with the effective collection of the tax but might seriously increase the difficulties of the retailer im fulfilling his obligation to collect the $\operatorname{tax}$.

Under such circumstances the tax might conceivably be viewed as on sales in interstate commerce. Such a view would find support in the fact that the use tax is patently a device for placing interstate retailers on the same footing with local retailers. When the Court in the Felt \& Tarrant case recognized the retailer's obligation to collect the tax it went far to destroy the convention which differentiates a use tax from a sales tax. There are strong indications that it will recognize outright the power of states not ouly to reach sales in interstate commerce directly rather than through taxes which are ostensibly upon use but also to make the retailer the taxpayer in form as well as in substance. ${ }^{5 T}$.

65 See Pierce Oil Corp. v. Hopkins (1924) 264 U. S. 137; Texas Co. v. Blue Way Lines Inc. (C. C.A. 1st, 1937) 93 F. (2d) 593, requiring collection by sellers of gasoline.

56 See Continental Supply Co. v. People (Wyo. March 21, 1939) 88 P. (2d) 488, invalidating a requirement for collection at time of sale.

57 See Graybar Electric Co. Inc. v. Curry (Nov. 6, 1939) 60 Sup. Ct. 139, 84 L. ed. Adv. Ops. 97, aff'g (Ala. May 25, 1939) 189 So. 186, reh'g den., (Dec. 4, 1939) 60 Sup. Ct. 259, 84 L. ed. Adv. Ops. 221. See also Thomas Reed Powell, Business Taxation and Interstate Commerce, in Proceednos of Natronar TAX Ass's (1937) 337; Lockhart, The Soles Tax in Interstate Commerce (1939) 52 HARv. L. REv. 617. 
In James v. United Artists Corp. ${ }^{58}$ a United States district court had enjoined the collection of a West Virginia tax on the ground that it imposed an unconstitutional burden on interstate commerce. ${ }^{50}$ The Supreme Court affirmed but on the ground that the statute as construed by it, in the absence of any state court interpretation, did not apply to the facts im issue. The statute imposed a tax on "every person engaging . . . within this state in the business of collecting incomes froin the use of real or personal property...." The objecting taxpayer was a foreign corporation which received payment in New York for the use of its films in West Virginia where it had no office or place of busmess. It periodically sent a solicitor into that state to obtain contracts for the showing of its pictures, and likewise distributed its films to West Virginia exhibitors who returned them after use to points outside the state. The exhibitors made payment by holding the United Artists Corporation's share of each night's receipts in trust until the picture's run was completed, and reimiting it thereafter to the corporation at points outside the state. The Court interpreted the statute as requiring the distributor to be present within the state and to collect therein the payments from the exhibitors. The United Artists Corporation did not come within either of these conditions.

The importance of the case lies not in its holding, which is merely statutory interpretation, but in its implications. The Court pointed out that the statute did not raise the issue of the right of a state to tax income derived from sources within it. In concluding its opinion the Court reiterated its view that there was "no legislative purpose in cases like the present to tax gross receipts apart from the business or activity of collecting them." ${ }^{\circ 1}$ The inference that a different conclusion might have been reached by the Court had the tax been on income finds support in the principle of Shaffer $v$. Carter ${ }^{62}$ that a

68 (Jan. 3, 1939) 305 U. S. 410.

$69 \mathrm{~A}$ three judge district court, in holding the tax an unconstitutional burden on interstate commerce, relied upon Binderup v. Pathe Exchange (1923) 263 U. S. 291, which held that the business of furnishing films through shipments in interstate coinmerce was interstate business notwithstanding that in accordance with the contracts the films were delivered through a local exchange through which they were first consigned and transported. The Binderup case, however, involved a question of federal regulation which the Court recognized could not be governed by cases involving state taxation of interstate coinmerce.

60 W. Va. Laws 1935 , c. 86,82 -(i).

61305 U. S. at 415.

62 (1920) 252 U.S. 37. 
state may tax the net income of nonresidents derived from property or busmess within the state. The United Artists Corporation clearly. derived mcome from property within the state even though not engaged in business there. The delivery of the films in interstate commerce did not make their subsequent use in West Virginia a part of an interstate transaction requirimg the application of the cumulative burdens doctrine. The use of the films was no more in interstate commerce than the use of the advertising cuts and mats delivered interstate in the Western Live Stock case or the retention and installation of the property in the Southern Pacific Co. and Pacific Telephone Co. cases. The nicome received for the use of the films is therefore not income from interstate commerce. Had the United Artists Corporation sold the films, West Virginia's power to tax a portion of the corporation's income from sales to West Virginia distributors would depend on the Court's acceptance of the inference in the Adams Manufacturing Co. case that taxable income is realized in the state wliere sales are solicited and obtained as well as in the state where the sales contracts are approved. This inference, while running counter to the conclusion of the circuit court of appeals in Commissioner v. East Coast Oil Co., that "the mere execution of the contracts" does not produce any profit, is consistent with the Supreme Court's own decisions. The Court in the East Coast Oil Co. case referred in support of its conclusion to the Supreme Court's opinion in Compañia General v. Collector. ${ }^{64}$ That case involved sales negotiated in the United States but approved in the Philippines, and held that the entire transaction resulting in a profit, with the exception of the negotiations in the United States preceding the sale, took place in the Philippines, and therefore the transactions were taxable under Philippine law. This language while supporting the conclusion that all of the income was taxable by the Philippines, does not lend itself to the conclusion that none of the profit was attributable to the negotiations in the United States.

There is a growing concern among the states with the problem of taxing interstate vehicles which use their highways. Dixie Ohio Express Co. v. State Revenue Commission ${ }^{65}$ placed in issue the constitutionality of the tax imposed by the Georgia Maintenance Tax Act on trucks, tractors, and trailers. The tax was graduated on trucks

63 (C. C. A. 5th, 1936) 85 F. (2d) 322, 323.

Bs (1929) 279 U. S. 306.

65 (Jan. 30, 1939) 306 U. S. 72. 
and tractors according to capacity and on trailers according to weight. The rate applicable to vehicles hauling for hire was greater than the rate applicable to other vehicles and the proceeds from the tax were allocated exclusively to rural post roads. The taxpayer was engaged exclusively in interstate commerce and used about one hundred vehicles on the highways of the state, but did not use the rural post roads to which the proceeds of the tax were allocated. The tax was upheld against contentions that it was repugnant to the commerce and equal protection clauses of the Federal Constitution.

The Court held that the tax was exacted as compensation for the use of the roads of the state $e^{66}$ and that it was immaterial that the state used "part or all of the proceeds for purposes other than the construction, improvement, or maintenance of its highways." the taxpayer may question the tax even if it is exacted as compensation for highway use whenever its amount appears to be unreasonable, the taxpayer in this case failed to prove such a contention. The Court demied the contention that the Act violated the equal protection clause by imposing higher taxes on vehicles hauling for hire, on the ground that such vehicles presumably used the roads to a larger extent than other vehicles. The case makes it clear that reasonable compensation to a state for the use of its highways may be measured by their value to the user rather than by expenditures made by the state in building, maintaining, and policing the highways.

In Clark v. Paul Gray, Inc., ${ }^{\text {s }}$ however, upholding the constitutionality of the California Caravan Act of $1937,{ }^{60}$ the Court discussed the reasonableness of the fees in terms of compensation to the state for the costs incurred as a result of the caravan traffic. The Act before the Court in the Clark case defines caravaning as the "transpor-

${ }^{66}$ Cf. Interstate Transit, Inc. v. Lindsey (1931) 283 U. S. 183, in which the tax was invalidated on the grounds that it did not appear to be exacted either for use of the highways or for the expense of regulating motor traffic, that the statute imposing it was a general revenue measure dealing with practically all taxes levied by the state, that the moneys derived from it went into the general funds of the state, and that in addition the amount of the tax was not dependent on the mileage traveled or the number of passengers carried.

67306 U. S. at 77. Cf. Morf v. Bingaman (1936) 298 U. S. 407, 412: “... where the manner of the levy, like that prescribed by the present statute, definitely identifies it as a fee charged for the grant of the privilege, it is immaterial whether the state places the fees collected in the pocket out of which it pays highway maintenance charges or in some other."

68 (April 17, 1939) 306 U. S. 583.

69 Cal. Stats. 1937, p. 2253. Enacted to replace the act held unconstitutional in Ingles v. Morf (1937) 300 U. S. 290, because the fees imposed were excessive. 
tation of any vehicle ... operated on its own wheels, or in tow of a motor vehicle, for the purpose of selling or offering the same for sale . . . within or without this State," 70 and exacts two license fees of $\$ 7.50$ each for a six months' permit for caravaning a vehicle on the highways of the state. It provides for two zones within the state and exempts intrazone movements from its provisions. While the annual graduated tax in the Dixie Ohio Express Co. case was exacted as compensation for the use of state highways, the Califorma Act provides for the exaction of one fee to reimburse the state for expenses incurred in administering police regulations incident to the Act and of another fee in return for the use of the state's highways.

The taxpayer, engaged in caravaning cars interstate for the purpose of sale in Califorma, contended that this activity could not be subjected to the Act without violating the commerce, due process, and equal protection clauses of the Constitution. The Court, citing the Dixie Ohio Express Co. case among others, declared that the commerce clause does not prevent states from imposing reasonable fees for the use of highways or from classifying vehicles according to their use of its highways, and concluded that the taxpayer had "failed to sustain the burden of proof that either of the fees is excessive for the purpose for which it is collected." 71 As for the due process and equal protection issues, the Court, relying upon Morf v. Bingaman, ${ }^{72}$ held that it was reasonable to classify separately vehicles coupled together and moved under the control of casual employees, and to impose fees both for use of the highways and expense of policing. The exemption of intrazone caravaning was likewise held reasonable since there was evidence that such caravaning caused fewer traffic problems and resulted in less wear and tear on the highways than the caravans driven to Califorma from other states. The Court likewise refused to consider whether there was an invalid discrimination as between cars driven into the state singly for sale, and those driven in singly for other purposes or those driven singly to inarket intrazone, for the appellee did not transport any cars singly or in intrazone movements, but moved all of its cars interstate in caravans of nineteen to twentyfive cars, and was therefore not in the class agamst which it alleged a discrimination existed.

The taxpayer made no attempt to show discrimination against

70 Cal. Stats. 1937, p. $2253, \S 1$.

71306 U. S. at 600 .

72 Supra note 67 . 
interstate commerce and since the Court did not suggest that taxes paid to other states were relevant to the question of unreasonableness such taxes presumably have no bearing on the question. A tax limited to interstate carriers would discriminate against interstate commerce under the rule of Welton $v$. Missouri, ${ }^{73}$ but one levied on both intrastate and interstate carriers would impose only such burdens on interstate carriers by reason of taxes paid to other states as were essentially similar to those recognized as legitimate in the Coverdale case. ${ }^{74}$

Florida's recent attempt to protect its cement industry from foreign competition was thwarted by the Court in Hale v. Bimco Trading $\mathrm{Co}^{75}$ The Florida statute stated that approximately thirty per cent of all cement sold and used in the state was imported from foreign countries, that much of it was of inferior quality, and that its use " "not only jeopardizes public safety but amounts to unfair competition being forced on this great industry in Florida.' "76 It authorized the State Roads Department to fix a minimum standard for all cement offered for sale, sold or used within the state and required an inspection and the payment of an inspection fee of fifteen cents per hundred weight for all cement brought into Florida from any foreign country.

The Court reasoned that an inspection of domestic cement would be as essential to "public safety" as that of foreign cement, which was discriminated against by an inspection fee amounting to sixty times the actual cost of inspection. The statutory reference to protection froin unfair competition was regarded by the Court as "a candid admission that the very purpose of the statute is to keep out foreign goods." 77 The statute was therefore clearly invalid under the commerce clause and its demise was hastened by the bald candor of its language.

Inter-Island Steam Navigation Co. v. Hawaii ${ }^{78}$ upheld the application of a tax ineasured by gross income, imposed under the Utjlities Act of 1913 of the Territory of Hawaii, to a common carrier of freight and passengers by water between different points in the Territory. A substantial part of its gross income was derived from transporting freight destined for trans-shipment to foreign or mainland

73 (1875) 91 U. S. 275.

74 Supra note 13.

75 (Feb. 27, 1939) 306 U. S. 375.

76 Ibid. at 379.

77 Ibid. at 380 .

78 (1938) 305 U. S. 306. 
points. After determining that it was not the intent of Congress that its Shipping Act of $1916^{79}$ wholly supersede the Territorial Act with regard to carriers like the petitioner, the Court held that even if it were assumed that the petitioner were engaged in interstate and forign commerce, Congress in the Act of 1916 had subjected petitioner to the territorial law under which the tax was levied and thereby exercised its power to regulate commerce by enabling the Territory to impose the tax. The Court held that, apart from its power under the commerce clause, Congress could subject the petitioner to the tax by virtue of its plenary authority over Territories of the United States.*

Roger John Traynor.

ScROOL OF JURISPRUDENCE,

UNIVERSITY OF CATIFORNIA.

*[This is the second of two articles on this subject. They are based upon papers read at the National Tax Conference, San Francisco, October 16 and 18, 1939.-ED.]

7939 STAT. (1916) 728, 46 U.S. C. (1934) §801 et seq. 